\title{
Gestational Trophoblastic Disease with Pulmonary and Cerebral Metastasis: Can Fluorodeoxyglucose Positron Emission Tomography Really Detect Cranial Metastatic Disease ?
}

\author{
Akciğer ve Beyin Metastazlı Gestasyonel Trofoblastik Hastalık: Pozitron Emisyon Tomografisi Kranial Metastatik \\ Hastalığı Saptayabiliyor mu?
}

Ulaș Kumbasar ${ }^{1}$, Serkan Uysal2 ${ }^{\text {, Tuba Kılıçer Șahinoğlu³ }}$, Sevgen Önder ${ }^{4}$, Metin Demircin ${ }^{1}$

Hacettepe University Medical Faculty Department of Thoracic Surgery
Bülent Ecevit University Medical Faculty Department of Thoracic

Sivas Numune Hospital Department of Thoracic Surgery

Hacettepe University Medical Faculty Department of Patholog.

Received: July 07, 2016• Accepted: September 19,2016

Corresponding Author:

Ulaș Kumbasar, MD

E-mail: ulaskumbasar@gmail.com

Phone: 00903123051774

Hacettepe University Medical Faculty Department of

Cardiovascular Surgery Sihhiye, Ankara

Gestational trophoblastic neoplasms (GTN) originate from placental tissue and usually metastasizes because of its propensity for early vascular invasion. Intracranial metastases are relatively uncommon. There are limited data on the efficacy of 18-fluorodeoxyglucose positron emission tomography (FDG-PET) in the evaluation of metastatic GTN. We present a case of GTN with simultaneous pulmonary and cranial metastases in which the cranial metasteses were undetectable with positron emission tomography (PET) scan.

Key Words: Gestational Trophoblastic Neoplasms, Cranial Metastasis, Positron Emission Tomography

Gestasyonel Trofoblastik Neoplaziler (GTN) plasenta dokusundan köken alırlar ve erken vasküler invazyon yaptıklarından sıklıkla metastaz yaparlar. Beyin metastazı nadir görülür. Metastatik GTN'nin taranmasında 18-florodeoksiglukoz pozitron emisyon tomografisinin (FDG-PET) etkinliği konusunda veriler yetersizdir. Bu olgu sunumunda, eș zamanlı akciğer ve beyin metastazı olan ve beyin metastazının FDG-PET ile saptanamadığı bir GTN olgusunu sunuyoruz.

Anahtar Sözcükler: Gestasyonel Trofoblastik Neoplazi, Beyin Metastazı, Pozitron Emisyon Tomografisi

Gestational trophoblastic neoplasms (GTN) originate from placental tissue and includes a spectrum of tumors ranging from hydatidiform mole to choriocarcinoma (1). These tumors can be cured even in the presence of widespread metastasis (2). The most common metastatic sites are the lung $(80 \%)$, vagina $(30 \%)$, brain $(10 \%)$ and liver $(10 \%)$ (3). $\beta$-human chorionic gonadotropin $(\beta-\mathrm{hCG})$ is a sensitive tumor marker that allows clinical assesment and follow-up. The treatment is mainly based on combination chemotherapy with the selective use of surgical treatment and radiation therapy for metastatic and/or resistant tumors (4). We present a case of GTN with simultaneous pulmonary and cranial metastases in which the cranial metasteses were undetectable with positron emission tomography (PET) scan.

\section{Case Report}

A 24-year-old woman admitted to another institution with irregular vaginal bleeding. Serum $\beta$-hCG value was $4458 \mathrm{mIU} / \mathrm{ml}$. Presuming gestational trophoblastic disease or ectopic pregnancy, diagnostic laparoscopy and dilatation/curettage (D\&C) were performed. No ectopic pregnancy was detected on laparoscopy. Histopathologic examination of $\mathrm{D} \& \mathrm{C}$ material revealed biphasic endometrium. Computed tomography (CT) of the abdomen and brain showed no abnormality. Magnetic resonans imaging (MRI) of the pelvis was also normal. The patient received four doses of methotrexate $(60 \mathrm{mg})$ and folic acid (6 mg). Following chemoteraphy serum $\beta$-hCG value was detected as $4572 \mathrm{mIU} / \mathrm{ml}$. 
Chest CT was performed and a $18 \mathrm{~mm}$ nodule was detected in the right middle lobe (Figure 1).

PET scan only showed a lung nodule, measuring $2.5 \times 1.8 \mathrm{~cm}$ with a standard uptake value (SUV) of 8.13 which was strongly suspicious for metastatic lesion (Figure2). Transthoracic fine needle aspiration of the nodule was nondiagnostic. The patient was referred to our institution for surgical resection of the nodule.

The patient underwent right thoracotomy. The nodule which was detected in the middle lobe was excised with wedge resection and sent for frozen section. Frozen section was considered as choriocarcinoma metastasis. During follow-up, on postoperative 8th hour the patient's level of consciousness was decreased and the respiration pattern became irregular. Physical examination revealed unclear consciousness, motor and sensorial disturbances and anisocoria which are associated with increased intracranial pressure. Emergent MRI of the brain showed two hemorrhagic metastatic lesions on the left side with surrounding edema one in the level of basal ganglions (Figure 3) and the other in the cerebellar hemisphere (Figure 4).

Medical anti-edema treatment was performed and the patient improved clinically. Whole-brain irradiation was planned and began with $300 \mathrm{cGy} /$ day subsequently. The patient recovered well and scheduled for chemotherapy.

\section{Discussion}

GTN include a spectrum of interrelated tumors including complete (CHM) and partial hydatidiform mole (PHM), invasive mole (IM), choriocarcinoma (CCA) and placental site trophoblastic tumor (PST'T), that have varying propensities for local invasion and spread (4). The incidence of this disease varies dramatically in different regions being highest in Asian countries with an incidence rate of one per every 2,000 pregnancies (5).

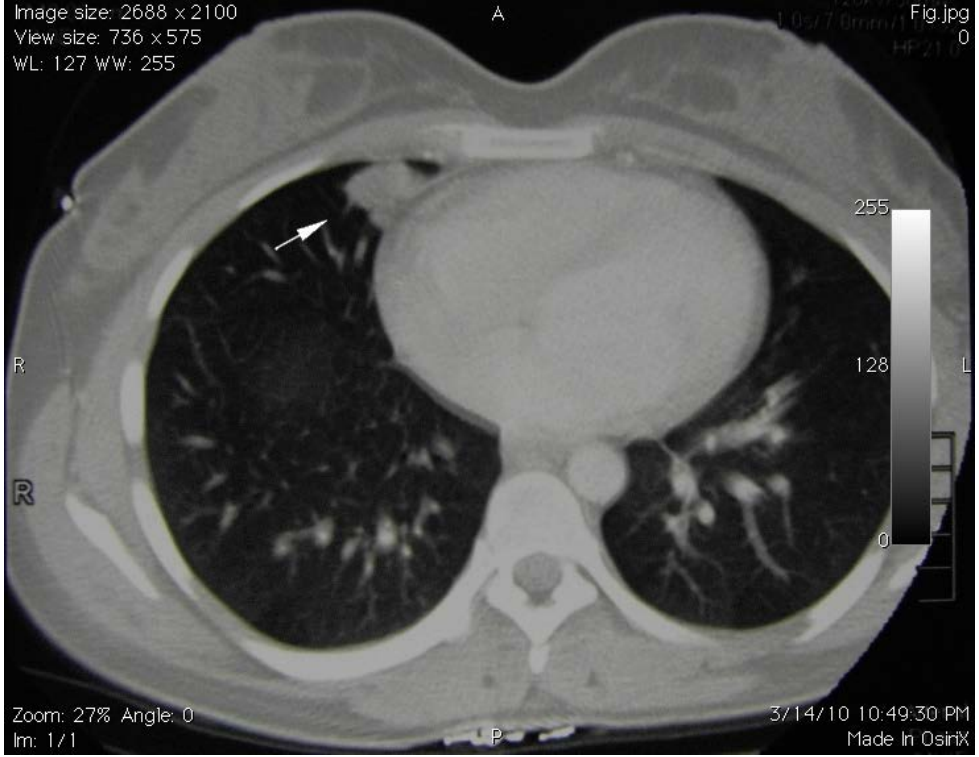

Figure 1: Nodule in the right middle lobe (white arrow).

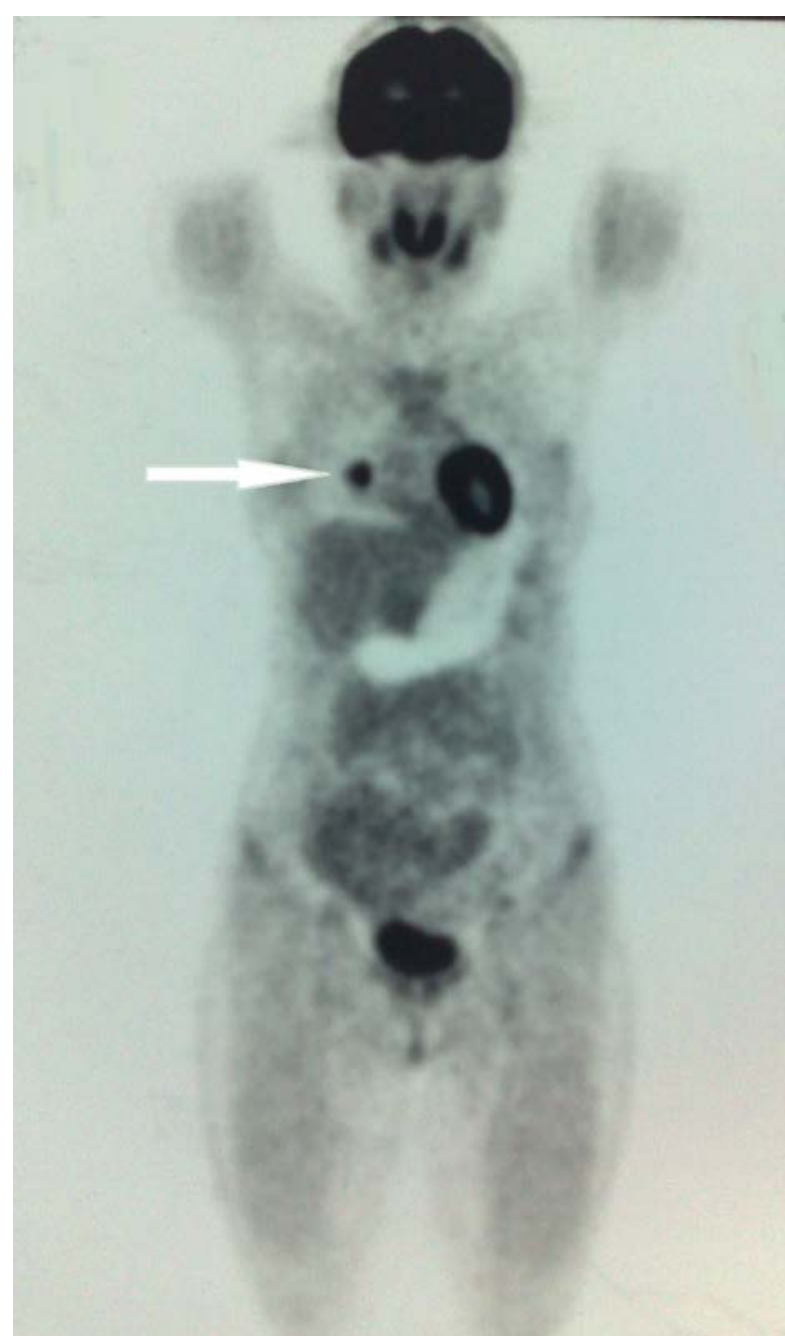

Figure 2: PET scan image - nodule in the lung (white arrow). 
GTN usually metastasizes as CCA because of its propensity for early vascular invasion with widespread dissemination. Because trophoblastic tumors are perfused by fragile vessels, metastases are often hemorrhagic. Patients with pulmonary metastases commonly have asymptomatic lesions on chest radiography or may present with dyspnea, chest pain, cough or hemoptysis $(4,6)$. Intracranial metastases are relatively uncommon having an incidence of 3-28\% in patients with GTN. Most patients with cerebral metastases are symptomatic and present with symptoms usually result from increased intracranial pressure or intracerebral bleeding (7).

The optimal management of GTN requires a throughout assessment of the extent of the disease. History and physical exam, measurement of hCG level, hepatic-renal functions should be included in this assessment (8). Several imaging modalities have been proposed to localize both the primary tumor and metastases. As for primary tumor detection, computed tomography (CT) or magnetic resonance (MR) imaging of the abdomen is considered useful and more specific than ultrasound. As for metastases, conventional imaging modalities may not show the foci of viable tumor. Newer modalities such as 18fluorodeoxyglucose positron emission tomography (FDG-PET) scans may accurately identify sites of metastases and help determine resectability $(9,10)$. PET is a noninvasive method for studying biochemical and metabolic changes in cancer tissue, as they reflect growth or regression of tumors. Yet, there are limited data on the efficacy of PET in the evaluation of metastatic GTN, with studies limited to case reports and small case series (11-14). Sironi et al (15). showed the usefulness of FDG-PET as an indicator of metastatic GTN in three patients. However, in that study the metastates were all located either in the lung or in the liver. None of them were cranial metastasis. In our case the cranial metastases could not be detected with PET-scan. The important reason for excluding brain is the intense FDG distribution normally seen in the brain tissue (16).

Management to metastatic GTN disease includes primary combination chemoteraphy with the selective use of radiation and surgical treatment. irradiation and systemic chemoteraphy should be instituted to reduce the risk of cerebral hemorrhage (4).

In conclusion, GTN disease should be evaluated in detail for posssible metastatic sites with appropriate diagnostic methods. We think that PET-scan does not seem convenient in GTN patients with suspected

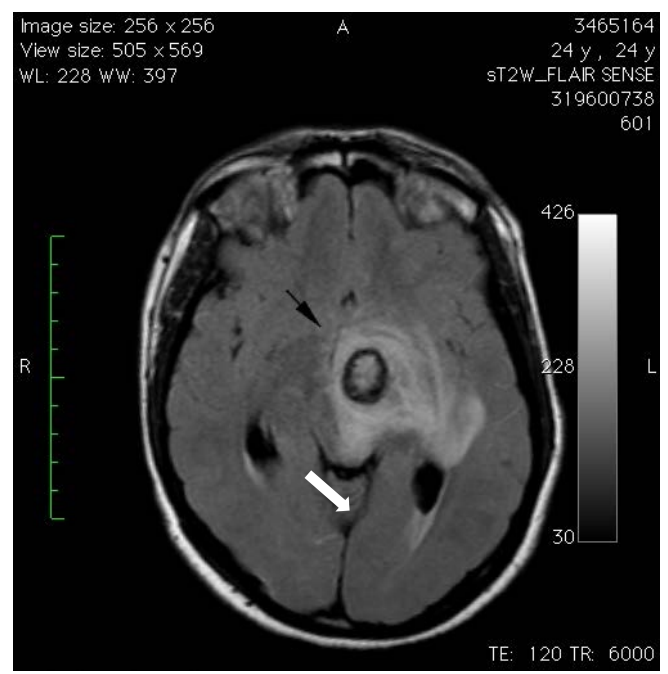

Figure 3: Hemorrhagic metastatic lesion with surrounding edema in the level of left basal ganglions (black arrow).

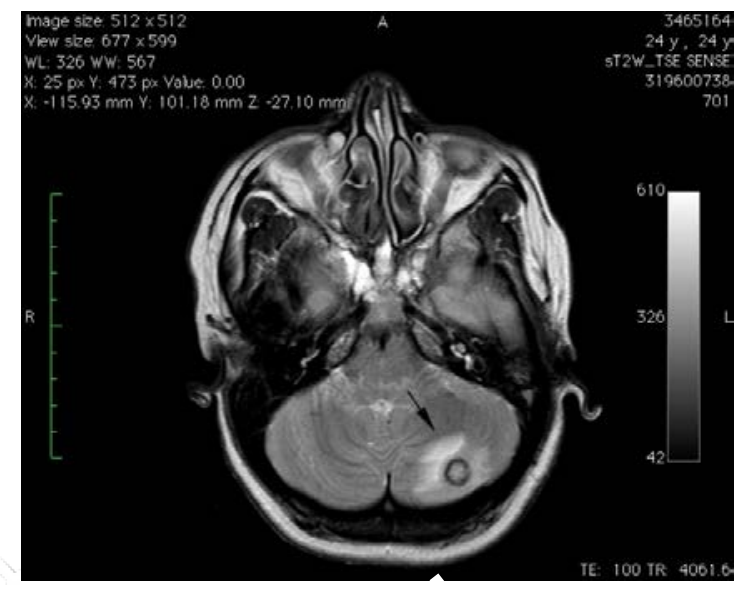

Figure 4: Metastatic lesion in the left cerebellar .iemisphere (black arrow).

Surgery is performed either to treat complications or to excise sites of resistant tumor. When cranial metastases are identified whole-brain metastatic disease and further studies comparing PET and conventional imaging techniques are needed to clarify the potential role of PET-scan. 


\section{REFERENCES}

1. Szulman AE. Trophoblastic disease: clinical pathology of hydatidiform moles. Obstet Gynecol Clin North Am 1988;15: 443-456.

2. Bagshawe KD. Risks and prognostic factors in trophoblastic neoplasia. Cancer 1976;38:1373-1385.

3. Berkowitz RS, Goldstein DP. Pathogenesis of gestational trophoblastic neoplasms. Pathobiol Ann 1981;11:391-411.

4. Berkowitz RS, Goldstein DP. Current management of gestational trophoblastic diseases. Gynecologic Oncology; 2003;112: 654-662.

5. Lathrop JC, Lauchlan S, Nayak R. Clinical characteristics of placental site trophoblastic tumor. Gynecol Oncol 1988;31:32-42.

6. Bagshawe KD, Noble MIM. Cardiorespiratory aspects of trophoblastic tumors. QJ Med 1966;137:39-54.
7. Suresh TN, Santosh V, Shastry Kolluri VR Intracranial haemorrhage resulting from unsuspected choriocarcinoma metastasis. Neurol India 2001;49:231-236.

8. Hammond CB, Weed JC, Currie JL. The role of operation in the current therapy of gestational trophoblastic disease. Amer J Obstet Gynecol 1980;136:844-856.

9. Watanabe AS, Smoker WR. Computed tomography and angiographic findings in metastatic choriocarcinoma. J Comput Assist Tomogr 1989;13:319-322.

10. Dhillon T, Palmieri C, Sebire NJ, et al. Value of whole body 18 FDG-PET to identify the active site of gestational trophoblastic neoplasia. J Reprod Med 2006;51:879-887.

11. Allen SD, Lim AK, Seckl MJ, Blunt DM, Mitchell AW. Radiology of gestational trophoblastic neoplasia. Clinical radiology 2006; 61:301-313.
12. Dose J, Bohuslavizki K, Huneke B, et al. Detection of intramural choriocarcinoma of the uterus with FDG-PET: a case report. Clin Positron Imaging 2000;3:37-40.

13. Hebart H, Erley C, Kaskas B, et al. Positron emission tomography helps to diagnose tumor emboli and residual disease in choriocarcinoma. Ann Oncol 1996;7:416418.

14. Zhuang H, Yamamoto AJ, Ghesani N, Alavi A. Detection of choriocarcinoma in the lung by FDG positron emission tomography. Clin Nucl Med 2001;26:723.

15. Sironi S, Pichio M, Mangili G, et al. Fluorodeoxyglucose positron emission tomography as a useful indicator of metastatic gestational trophoblastic tumor: preliminary results in three patients. Gynecologic oncology 2003;91:226-230.

16. Coleman RE. PET in lung cancer staging. Q J Nucl Med. 2001;45:231-234. 